\title{
An outbreak of
}

\section{Pseudomonas aeruginosa (pyocyanea) infection in a Premature Baby Unit, with observations on the intestinal carriage of Pseudomonas aeruginosa in the newborn}

\author{
By C. H. JELLARD AND GILLIAN M. CHURCHER \\ Public Health Laboratory Service and Department of Pathology \\ Plymouth General Hospital, Greenbank Road, Plymouth
}

(Received 2 January 1967)

\section{INTRODUCTION}

Pseudomonas aeruginosa (pyocyanea) infection may occur sporadically, or in outbreaks. It is well recognized that the newborn, and in particular premature babies, are very susceptible to infection with $P$ s. aeruginosa which may vary from symptomless carriage of the organism to a fulminating septicaemia.

This paper describes an outbreak of infection in a Premature Baby Unit, with predominantly intestinal and respiratory signs, which was caused by a single strain of $P s$. aeruginosa. The outbreak lasted for 16 months because of the persistent carriage of $P$ s. aeruginosa in the faeces of the babies, many of whom were symptom free.

\section{BACTERIOLOGICAL METHODS}

Faeces were cultured on $\mathbf{0 . 0 3} \%$ cetrimide nutrient agar (Lowbury \& Collins, $1955)$ and incubated for $18-24 \mathrm{hr}$. at $37^{\circ} \mathrm{C}$. No enrichment media were used.

In environmental investigations, surfaces of equipment were swabbed with cotton-wool swabs which had been moistened with nutrient broth. The swabs were incubated in tubes of broth for $24 \mathrm{hr}$. at $37^{\circ} \mathrm{C}$. and then subcultured on cetrimide agar and incubated for a further $24 \mathrm{hr}$. at $37^{\circ} \mathrm{C}$. Cetrimide agar settle plates were exposed for 1-2 hr. and then incubated for $24 \mathrm{hr}$. at $37^{\circ} \mathrm{C}$. Liquid samples were diluted 1/10 with nutrient broth and incubated for $72 \mathrm{hr}$. at $37^{\circ} \mathrm{C}$. Liquid disinfectants were also tested by the method described by Kelsey \& Maurer (1966).

$P s$. aeruginosa was identified by the morphology and colonial appearance, the formation of pigment, the characteristic smell and a positive oxidase reaction (Kovacs, 1956). Non-pigmented forms were not found. If there was doubt about the identification, subculture was made, to enhance pigment formation, on Wahba \& Darrell's (1965) modification of Sierra's (1957) medium, which was incubated for $24 \mathrm{hr}$. at $37^{\circ} \mathrm{C}$.

Bacteriophage typing of selected strains was carried out at the Cross-Infection Reference Laboratory of the Public Health Laboratory Service. 


\section{THE PREMATURE BABY UNIT}

Most of the premature babies were delivered in the labour wards or operating theatre of the Maternity Department, and were transferred to the Premature Baby Unit immediately after birth for an average of $\mathbf{3}$ weeks. Healthy full-term babies went to the maternity wards with their mothers.

For the first 9 months of the investigation the Premature Baby Unit had accommodation for 14 babies; the premises were very overcrowded and unsatisfactory, and there were no isolation facilities. From the end of January 1966, during the latter part of the outbreak, the Premature Baby Unit was transferred to a newly designed modern ward with accommodation for 24 babies, which was divided into cubicles.

In the early weeks of the outbreak the infants' feeds were prepared in the Premature Baby Unit; later the feeds were prepared and terminally sterilized in a central milk kitchen in a different part of the building.

Before use, the inner and outer surfaces of the premature babies' incubators were cleaned with $2.0 \%$ Printol (a clear soluble phenolic fluid); the interior of the incubators was then treated with formaldehyde gas. Bacteriological checks of the incubators showed that the disinfection was effective.

\section{THE OUTBREAK}

Between 22 April 1965 and 6 August 1966, 418 babies were admitted to the Premature Baby Unit. The birth weight of nearly all the babies was less than 2500 g. (5 $\frac{1}{2}$ lb.). Ps. aeruginosa was cultured from the faeces of 99 babies; cultures from 62 of these, taken at random at different times during the outbreak, were typed and with one exception they had the phage-typing pattern 7/16/21/44/68/ F8/109/119x/352/1214/M4. There were seven deaths due to $P$ s. aeruginosa infection (Table 1). Infections of nose (2), throat (4), eye (2), ear (2), vagina (2), skin (2), due to $P s$. aeruginosa also occurred during this period.

As a routine, faeces from all babies are examined bacteriologically every week. The unit had been remarkably free from infection during the year before the investigation. Early in April 1965, Ps. aeruginosa was isolated more and more often from the babies' faeces (although selective cetrimide medium was not in use at that time). The significance of this finding was not appreciated until later in the month, when infection in three babies became clinically apparent, one baby developing a skin infection, another a nasal infection and the third a throat infection, which were all due to Ps. aeruginosa. At that time, it was suspected that the source of this infection was either an aspirator in the labour ward, which was used for the resuscitation of newborn babies and was heavily contaminated with Ps. aeruginosa, or a member of the Premature Baby Unit staff who had a chronic otitis externa, due to $P s$. aeruginosa. However, in both instances, phage typing showed these strains to be different from the epidemic strain, and the original source of the infection was not discovered.

Table 2 summarizes the positive findings of bacteriological examination of the equipment in the labour wards, maternity operating theatre and Premature Baby 
Unit. A total of 210 swabs was taken from different sources, including medicines, hand lotions, soap, distilled water, saline solutions, incubators, babies' feeds and bottles. Ps. aeruginosa was isolated on 23 occasions. In spite of the continued faecal

Table 1. Deaths due to Pseudomonas aeruginosa infection

\begin{tabular}{|c|c|c|c|c|c|c|c|}
\hline Case & $\begin{array}{c}\text { Date of } \\
\text { birth }\end{array}$ & Sex & $\begin{array}{c}\text { Birth } \\
\text { weight } \\
\text { (g.) }\end{array}$ & $\begin{array}{l}\text { Age at } \\
\text { death } \\
\text { (days) }\end{array}$ & Clinical findings & \multicolumn{2}{|l|}{$\begin{array}{l}\text { Bacteriological } \\
\text { findings }\end{array}$} \\
\hline 1 & 20. v. 65 & $\begin{array}{l}F, \\
\text { twin }\end{array}$ & 1930 & 12 & Septicaemia & \begin{tabular}{l} 
Faeces \\
Blood culture \\
Post mortem \\
$\quad$ Meninges \\
\multicolumn{1}{c}{ Pericardium }
\end{tabular} & $\begin{array}{l}\dagger \mathrm{Ep} \\
\dagger \mathrm{Ep} \\
\dagger \mathrm{Ep} \\
*\end{array}$ \\
\hline 2 & 28. vi. 65 & $\mathbf{M}$ & 1680 & 10 & $\begin{array}{l}\text { Respiratory } \\
\text { distress syndrome, } \\
\text { septicaemia }\end{array}$ & $\begin{array}{l}\text { Throat } \\
\text { Post mortem } \\
\quad \text { Pericardium } \\
\text { Bronchi } \\
\text { Meninges }\end{array}$ & $\begin{array}{l}* \\
* \\
* \\
\dagger E p\end{array}$ \\
\hline 3 & 11. vii. 65 & $\mathbf{F}$ & 1445 & 11 & Septicaemia & $\begin{array}{l}\text { Faeces } \\
\text { Post mortem } \\
\quad \text { Meninges } \\
\text { Pericardium } \\
\text { Bronchi }\end{array}$ & $\begin{array}{l}\dagger \mathrm{Ep} \\
\dagger \mathrm{Ep} \\
* \\
*\end{array}$ \\
\hline 4 & 8. i. 66 & $\mathbf{M}$ & 1810 & 10 & $\begin{array}{l}\text { Abdominal dis- } \\
\text { tension, ileus, } \\
\text { laparotomy, } \\
\text { gangrene of } \\
\text { transverse colon, } \\
\text { septicaemia }\end{array}$ & $\begin{array}{l}\text { Blood culture } \\
\text { Mouth } \\
\text { Faeces } \\
\text { Peritoneum }\end{array}$ & $\begin{array}{l}\dagger \mathrm{Ep} \\
* \\
* \\
*\end{array}$ \\
\hline 5 & 9. iii. 66 & $\begin{array}{l}\text { M, } \\
\text { twin }\end{array}$ & 1560 & 11 & $\begin{array}{l}\text { Respiratory dis- } \\
\text { tress syndrome, } \\
\text { abdominal dis- } \\
\text { tension, septic- } \\
\text { aemia }\end{array}$ & $\begin{array}{l}\text { Faeces } \\
\text { Post mortem } \\
\text { Bronchi } \\
\text { Small intestine } \\
\text { Meninges }\end{array}$ & $\begin{array}{l}\dagger \mathrm{Ep} \\
* \\
* \\
\dagger \mathrm{Ep}\end{array}$ \\
\hline 6 & 25. iii. 66 & $\mathbf{F}$ & 1470 & 50 & $\begin{array}{l}\text { Respiratory dis- } \\
\text { tress syndrome, } \\
\text { diarrhoea with } \\
\text { blood, septic- } \\
\text { aemia }\end{array}$ & Faeces & $\dagger \mathrm{Ep}$ \\
\hline 7 & 15. iv. 66 & $\begin{array}{l}\text { M, } \\
\text { twin }\end{array}$ & 1100 & 13 & $\begin{array}{l}\text { Respiratory dis- } \\
\text { tress syndrome, } \\
\text { diarrhoea, septic- } \\
\text { aemia }\end{array}$ & Faeces & $\dagger \mathrm{Ep}$ \\
\hline
\end{tabular}

excretion of Ps. aeruginosa during the outbreak the epidemic strain was only isolated twice-from a small mop on 12 October 1965, and from a nail brush on 14 October 1965-in the Premature Baby Unit. Both mop and nail brush were immersed in $2.0 \%$ 'Printol' when sampled. Settle plates failed to show evidence of airborne infection.

In view of the work of Wilson, Nelson, Phillips \& Boak (1961), a special 
investigation was made of the tap aerators and theoutlet of the wash-basins and the sinks. Ps. aeruginosa was not isolated from the aerators or taps, but was present in all 36 of the basin and sink outlets tested. The epidemic strain was not found. Each ward had its own predominant basin and sink outlet strain of Ps. aeruginosa. Although we could find no evidence to suggest a relationship between the $P$ s. aeruginosa in the basins and sinks and human infection, we agree with Wilson et al. that this is a potential source of infection. There is no effective way of sterilizing these outlets and there is a need, in hospitals, for an outlet that can be easily disinfected and made safe.

Table 2. Sources of Pseudomonas aeruginosa from the environment (excluding basins and sinks)

\begin{tabular}{|c|c|c|c|}
\hline $\begin{array}{l}\text { Maternity } \\
\text { operating } \\
\text { theatre }\end{array}$ & $\begin{array}{l}\text { 2. vi. } 65 \\
\text { 18. viii. } 65 \\
\text { 15. x. } 65 \\
\text { 8. iii. } 66\end{array}$ & $\begin{array}{l}\text { Rubber tubing in sluice } \\
\text { Floor } \\
\text { Nail brush } \\
\text { Mop }\end{array}$ & $\begin{array}{l}7 / 21 / 68 / 119 x / \mathrm{M} 4 \\
\mathrm{~N} / \mathrm{T} \\
\mathrm{N} / \mathrm{T} \\
\mathrm{N} / \mathrm{T}\end{array}$ \\
\hline $\begin{array}{l}\text { Labour } \\
\text { ward }\end{array}$ & $\begin{array}{l}\text { 20. iv. } 65 \\
\text { 31. v. } 65 \\
\text { 12. vi. } 65 \\
\text { 13. viii. } 65 \\
\text { 13. viii. } 65 \\
\text { 14. i. } 66\end{array}$ & $\begin{array}{l}\text { Aspirator } \\
\text { Aspirator } \\
\text { Aspirator } \\
\text { Bucket } \\
\text { Bucket } \\
\text { Bucket }\end{array}$ & $\begin{array}{l}31 \\
7 / 31 / 73 / 119 x \\
7 / 31 / 73 / 119 x \\
31 \\
31 \\
N / T\end{array}$ \\
\hline $\begin{array}{l}\text { Premature } \\
\text { Baby } \\
\text { Unit }\end{array}$ & $\begin{array}{l}\text { 12. x. } 65 \\
12 . x .65 \\
12 . x .65 \\
14 . x .65 \\
\text { 14. i. } 66 \\
\text { 14. i } 66 \\
\text { 14. i. } 66 \\
\text { 14. i. } 66 \\
\text { 14. i. } 66\end{array}$ & $\begin{array}{l}\text { Mop in 'Printol' } \\
\text { Soapy water in bucket } \\
\text { Mops in 'Printol' } \\
\text { Nail brush in 'Printol' } \\
\text { Bowl } \\
\text { Bucket } \\
\text { Mop } \\
\text { Water on floor } \\
\text { Bucket containing 'Printol' }\end{array}$ & $\begin{array}{l}7 / 16 / 21 / 44 / 68 / \mathrm{F} 8 / 109 / 119 \times / \\
352 / 1214 / \mathrm{M}^{*} \\
\mathrm{~N} / \mathrm{T} \\
7 / 53+ \\
7 / 16 / 21 / 44 / 68 / \mathrm{F} 8 / 109 / 119 \times / \\
352 / 1214 / \mathrm{M} \mathrm{4}^{*} \\
\mathrm{~N} / \mathrm{T} \\
\mathrm{N} / \mathrm{T} \\
\mathrm{N} / \mathrm{T} \\
68 \\
\mathrm{~N} / \mathrm{T}\end{array}$ \\
\hline $\begin{array}{l}\text { Maternity } \\
\text { ward }\end{array}$ & $\begin{array}{l}12 . \times 665 \\
12 . \times 65 \\
14 . \times 65 \\
17 . \times 65\end{array}$ & $\begin{array}{l}\text { Aspirator } \\
\text { Nail brush } \\
\text { Bucket } \\
\text { Bottle brush }\end{array}$ & $\begin{array}{l}7 / 31 / 73 \\
\mathrm{~N} / \mathrm{T} \\
31 \\
68+\end{array}$ \\
\hline
\end{tabular}

\section{Examination of faeces}

Because of the failure to find a source or reservoir of infection in the environment of the ward or operating theatre, nose and throat swabs and specimens of faeces were obtained from the staff, and the faeces of all babies, both full term and premature, were examined. Ps. aeruginosa was not isolated from the staff.

\section{Premature babies}

Figure 1 shows the results of a weekly survey of the faeces of the babies in the Premature Baby Unit. Most of those babies who acquired Ps. aeruginosa did so during the first 2 weeks of life. 
In order to determine the duration of faecal excretion of Ps. aeruginosa, 10 premature babies were followed up after they had left hospital, and samples of their faeces were examined at weekly intervals. When, for administrative reasons, this investigation was stopped, five of the babies were still excreting $P$ s. aeruginosa in their faeces 2 months after they were first found to be faecal carriers.
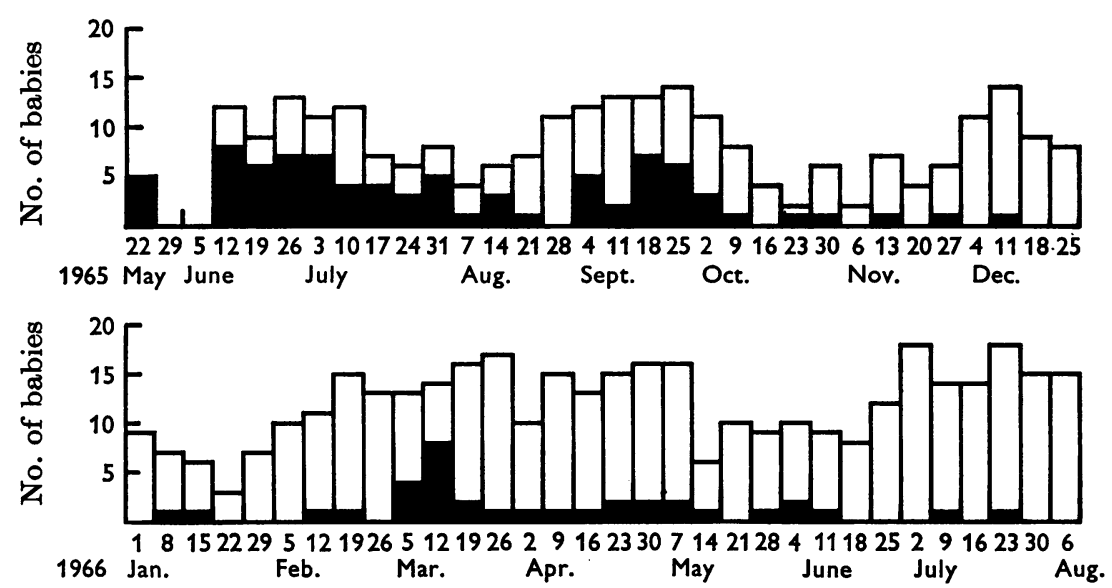

Fig. 1. Weekly isolations of Pseudomonas aeruginosa from faeces of babies in the Premature Baby Unit. $\square=P$ s. aeruginosa isolated from faeces; $\square=P s$. aeruginosa not isolated from faeces

Table 3. Monthly examination of faeces of full-term babies in maternity wards

1965 1966 June July Aug. Sept. Oct. Nov. Dec. Jan. Feb. Mar. April

$\begin{array}{lccccccccccr}\begin{array}{c}\text { Ps. aeruginosa } \\ \text { absent }\end{array} & 33 & 33 & 38 & 23 & 39 & 15 & 33 & 34 & - & 31 & 18 \\ \begin{array}{l}\text { Ps. aeruginosa } \\ \text { present }\end{array} & 34 & 4 & 11 & 0 & 0 & 1 & 1 & 0 & - & 1 & 0 \\ \begin{array}{c}\text { Epidemic strain } \\ \text { of } \begin{array}{c}\text { Ps. aerugi- } \\ \text { nosa }\end{array}\end{array} & 20 / 21 & 4 / 4 & 5 / 5 & - & - & 1 / 1 & 1 / 1 & - & - & 1 / 1 & - \\ \end{array}$

Thirty-three strains of Ps. aeruginosa were typed; of these, 32 were the epidemic strain.

\section{Full-term babies}

Table 3 shows that, on 2 June 1965, 34/67 normal full-term babies in the Maternity Department wards were excreting Ps. aeruginosa in their faeces, many of them in large numbers. Twenty-one strains from these babies were phage typed; 20 belonged to the epidemic strain. All these babies were well and had no symptoms of infection, except one baby who had mild diarrhoea. Monthly bacteriological examination showed a reduction in the faecal carrier rate of these babies which may have been due to improvement in hygiene after the recognition of the infection. 


\section{Reservoir of infection and means of spread}

Because Ps. aeruginosa was not found in the environment, we considered that the babies' faeces were the main reservoir that maintained the infection, for the faeces and nappies were always a prolific source of the organism. The infection was probably spread from baby to baby by contact, by way of the nurses' hands.

\section{DISCUSSION}

Many outbreaks of neonatal $P$ s. aeruginosa infection, mainly affecting premature babies, have been reported from the Continent and from the U.S.A., but there have been comparatively few reports from this country. The subject has been reviewed by Alison (1961) and by Paul \& Marget (1964).

The infection may affect various parts of the body, such as the respiratory tract, skin, eyes and meninges. Kwantes (1960) described a small outbreak in which middle ear infection predominated, with symptomless intestinal carriage of $P s$. aeruginosa. The intestinal tract is most commonly affected and outbreaks characterized by gastro-intestinal manifestations, such as feeding disturbances, abdominal distension, diarrhoea, intestinal ileus, haemorrhage, mucosal ulceration and intestinal perforation, have been reported (Schaffer \& Oppenheimer, 1948; Bielicka \& Dzieniszewska, 1953; Brádaĉ, Procházková \& Sedlák, 1954; Neter \& Weintraub, 1955; Verger \& Bentégeat, 1955; Eggers \& Wöckel, 1958; v. Gavallér, 1958; Jacobs, 1964; Bassett, Thompson \& Page, 1965).

Ps. aeruginosa is not a usual commensal organism of the intestinal tract in infants. McFarlan, Crone \& Tee (1949 and personal communication) failed to find it in the faeces of 385 babies from two maternity units; it has been isolated many times from healthy newborn babies in other hospitals, although sometimes it has caused severe illness. In the outbreak described by Bielicka \& Dzieniszewska, 70 babies had severe toxic enteritis; these authors and Linde, Koditz \& Kittlick (1962) have postulated a secondary infective factor-possibly a virus or unidentified bacterium - which would enable $P$ s. aeruginosa to act as an intestinal pathogen. Different strains of $P$ s. aeruginosa may vary in pathogenicity, which might account for the variation in severity of different outbreaks. In an outbreak quoted by Verger \& Bentégeat (1955), eight babies in a premature baby unit had severe diarrhoea and six of them died from the infection. In the present outbreak, although different non-epidemic strains of $P$ s. aeruginosa were isolated from equipment, wash basins and sink outlets, they were never found to colonize the babies' intestines (or to cause any other infection). This might indicate a difference in the ability of different strains to infect the intestine (with or without symptoms) and that the epidemic strain had an affinity for the intestine. The maturity of the baby might also influence the course of the infection. Linde et al. (1962) observed that the incidence of symptomless intestinal carriage increased with the age of the baby. In our investigations we found that 34/67 (51 \%) full-term babies in the maternity unit were excreting $P$ s. aeruginosa in their faeces; with one exception these babies were symptom free. It was only in the Premature Baby Unit that this organism 
behaved as a pathogen. An epidemic of infection was occurring in full-term babies, but because of their greater resistance to infection they were not ill.

Why should $P s$. aeruginosa be so much more pathogenic to premature than to full-term and older babies, and why is infection becoming more frequent? The following suggestions have been made:

(1) Premature babies may be more susceptible because they lack antibodies. Gitlin, Rosen \& Michael (1963) showed that newborn babies were deficient in the bactericidin to Gram-negative intestinal bacilli; the transfer of plasma gammaglobulin fractions across the placenta is selective and $19 \mathrm{~S}$ gamma-globulin, which includes the gram negative bacillus bactericidin, does not cross the placental barrier and is absent from the plasma of the newborn. The experiments of Jones \& Lowbury (1965) who protected mice from Ps. aeruginosa septicaemia by passive immunisation with human serum containing antibody to $P$ s. aeruginosa, show the ability of humoral antibodies to control the infection.

(2) Pseudomonas infection in children has become progressively more common since antibiotics were introduced about 15 years ago (Asay \& Koch, 1960). The increase of infections has been attributed to the use of antibiotics which suppress the antibiotic-sensitive commensal organisms and favour the selection of resistant species such as Ps. aeruginosa. In the early stages of the outbreak, many of the premature babies were having prophylactic treatment with penicillin and streptomycin, which may have made them more susceptible to infection.

(3) Hoffman \& Finberg (1955) suggested that the high humidity in the babies' incubators favoured the multiplication of $P$ s. aeruginosa.

(4) The incidence of $P s$. aeruginosa infection may still be rising because of the survival of more premature babies with modern methods of treatment and intensive care.

The next point to consider is the source or reservoir of the organism. In other studies various sources have been incriminated such as polluted milk (Hunter \& Ensign, 1947); contaminated suction apparatus (Bassett et al. 1965; Rubbo, Gardner \& Franklin, 1966) and contaminated babies' incubators (Barrie, 1965). Verger \& Bentégeat (1955) give evidence that the origin of a severe outbreak of infection in their Centre for Premature Babies was a baby who came from another hospital and developed a severe generalized skin infection due to $P$ s. aeruginosa soon after admission to the Centre. In at least three previous outbreaks, the commonest source of $P$ s. aeruginosa was the babies' faeces. Bielicka \& Dzieniszewska found 125/170 (73\%) babies were excreting $P$ s. aeruginosa in the faeces and 98 were symptom-free; in Neter \& Weintraub's study $71 / 143(50 \%)$ of the babies had Ps. aeruginosa in their faeces and most of them were healthy; $P s$. aeruginosa was cultured from the faeces of $17 / 21$ babies in Verger \& Bentégeat's epidemic. The reservoir of infection in the present outbreak was also the babies' faeces, the most probable path of infection being by way of the nurses' hands-the organisms not always being removed by soap and water-to infect another baby during feeding, possibly by contamination of the teats (Florman \& Schifrin, 1950; McLeod, 1958; Primavesi, 1964).

There are striking similarities between this outbreak in premature babies and 
an epidemic of Ps. aeruginosa septicaemia in irradiated mice and rats, described by Wensinck, Van Bekkum \& Renaud (1957) in which infection was caused by contamination of drinking devices by faecal excreters of $P$ s. aeruginosa; the epidemic was controlled by elimination of the faecal carriers and sterilization of the drinking bottles.

The type of outbreak described in this paper is difficult to control. The staff should be fully aware of the possible means of spread of the infection and should carry out the every-day routine preventive procedures with meticulous care. This is particularly important because of the unreliable action of liquid disinfectants on Ps. aeruginosa. The P.H.L.S. committee report (1965) on the use of liquid disinfectants in hospitals, advises that physical methods (heat) be used whenever possible, because of the uncertain action of these disinfectants. Kelsey \& Maurer (1966) showed how inadequate these disinfectants may be in general use; in different hospitals, vegetative organisms were recovered from buckets and jars which contained various phenolic disinfectants. Our findings also expose these drawbacks, which are all the more obvious when pseudomonads-which are more resistant to disinfectants than most vegetative organisms-are present. Brushes and mops should not be used, unless they are disposable or can be sterilized (by heat) after every use. If the staff rely only on disinfectants, they may wrongly assume that materials are sterile.

Ideally, the following measures are recommended to control the spread of infection:

(1) The babies should be nursed with isolation precautions in separate cubicles.

(2) Nurses who change nappies should not feed babies.

(3) Dirty nappies should be changed with extreme care and put directly into disposable polythene bags.

(4) Disposable gloves should be worn whenever the baby is handled, because it is difficult to ensure that the hands are completely free of $P$ s. aeruginosa after contamination, owing to the resistance of Ps. aeruginosa to soap and water and to disinfectants.

(5) To exclude $P$ s. aeruginosa, regular bacteriological screening tests should be made on the faeces of all premature babies, using a selective culture medium.

These procedures are time-consuming, and shortage of staff may make it diffcult for them to be properly carried out.

Because so many of the infected babies are free of symptoms, the results of measures to control infection are not clinically apparent, and it may be difficult to keep the staff enthusiastic about the strict discipline which is necessary. The gravity of the situation, where $P s$. aeruginosa is spreading silently through a premature baby unit, may not be appreciated until serious infection and deaths occur. 'Il faut redouter le pseudomonas'-pseudomonas must be feared (Alison, 1961) - and everyone should be fully aware of these often hidden but potentially dangerous infections of premature babies in hospitals. 


\section{SUMMARY}

An outbreak of infection in a Premature Baby Unit due to a single strain of Pseudomonas aeruginosa is described. The outbreak lasted for 16 months, during which this organism was isolated from the faeces of $99 / 418$ premature babies, many of them being symptomless carriers. There were seven deaths due to the infection. The source of the epidemic was not found. The main reservoir of infection was the babies' faeces. Though many full-term babies were symptomless carriers of the epidemic strain of $P$ s. aeruginosa, they were not ill.

Measures for control of the outbreak, and the aetiology of neonatal intestinal infection with Ps. aeruginosa are discussed.

We wish to thank Dr J. N. Montgomery for his help and for giving us access to his clinical notes.

We are indebted to Dr M. T. Parker and Mrs E. A. Asheshov of the CrossInfection Reference Laboratory, Colindale, for phage-typing numerous cultures of $P$ s. aeruginosa and for helpful discussion.

\section{REFERENCES}

AuIson, F. (1961). Infections à Pseudomonas aeruginosa chêz le nouveau-né et le nourrisson. Actual. pédiat. 3rd ser. p. 321.

Asay, L. D. \& KOCH, R. (1960). Pseudomonas infections in infants and children. New Engl. J. Med. 262, 1062.

BARRIE, D. (1965). Incubator-borne Pseudomonas pyocyanea infection in a newborn nursery. Archs. Dis. Childh. 40, 555.

Bassett, D. C. J., Thompson, S. A. S. \& Page, B. (1965). Neonatal infections with Pseudomonas aeruginosa associated with contaminated resuscitation equipment. Lancet $\mathrm{i}, 781$.

BIELICKa, I. \& DzIEnIszewska, L. (1953). Zakazenie paleczka ropy blekitnej u wcześniaków. Polski Tygod. lek. 8, 1413.

Brádaĉ, O., Procházková, R. \& Sedlák, J. (1954). Epidemie smrtelných prủjmù novorozencú s nálezem Pseudomonas aeruginosa (B. pyocyaneus). Pediat. Listy 9, 229.

EGGERs, H. \& Wöckes, W. (1958). The clinical picture and pathology of pyocyaneus infection in premature and full term neonates. Germ. med. Mon. 3, 45.

Florman, A. L. \& SchIFrIN, N. (1950). Observations on a small outbreak of infantile diarrhoea associated with Pseudomonas aeruginosa. J. Pediat. 36, 758.

Gavallér, B. v. (1958). Veränderungen durch Pyocyaneus bei Neugeborenen. Verh. dt. Ges. Path. 41, 213.

Giturn, D., Rosen, F. S. \& Mrchael, J. G. (1963). Transient 19S gamma-globulin deficiency in the newborn infant and its significance. Pediatrics, Springfield 31, 197.

Hofrman, M. A. \& Finberg, L. (1955). Pseudomonas infections in infants associated with high humidity environments. J. Pediat. 46, 626.

HUNTER, C. A. \& Ensian, P. R. (1947). An epidemic of diarrhoea in a newborn nursery caused by Pseudomonas aeruginosa. Am. J. publ. Hlth. 37, 1166.

JACOBS, J. (1964). The investigation of an outbreak of Pseudomonas pyocyanea infection in a pediatric unit. Post-grad. med. J. 40, 590.

JoNes, R. I. \& LowbURy, E. J. L. (1965). Susceptibility of man to Pseudomonas aeruginosa. Lancet ii, 623.

Kelsey, J. C. \& MaURer, I. M. (1966). An in-use test for hospital disinfectants. Mon. Bull. Minist. Hlth 25, 180.

Kovacs, N. (1956). Identification of Pseudomonas pyocyanea by the oxidase reaction. Nature, Lond. 178, 703. 
Kwantes, W. (1960). An outbreak of acute otitis media in a maternity hospital due to Pseudomonas aeruginosa. Mon. Bull. Minist. Hlth 19, 169.

Linde, K., Koditz, H. \& Kitruick, M. (1962). Untersuchungen zur Frage der Säuglingsenteritis durch Pseudomonas aeruginosa. Mschr. Kinderheilk. 110, 62.

LowBuRY, E. J. L. \& Collins, A. G. (1955). The use of a new Cetrimide product in a selective medium for Pseudomonas pyocyanea. J. clin. Path. 8, 47.

McFarlan, A. M., Crone, P. B. \& Tee, G. H. (1949). Variations in bacteriology of throat and rectum of infants in two maternity units. Br. med. J. ii, 1140.

McLeOD, J. W. (1958). The hospital urine bottle and bedpan as reservoirs of infection by Pseudomonas. Lancet i, 394.

Neter, E. \& Weintraub, D. H. (1955). An epidemiological study on Pseudomonas aeruginosa (Bacillus pyocyaneus) in premature infants in the presence and absence of infection. J. Pediat. 46, 280.

Paul, R. \& Marget, W. (1964). Pseudomonas aeruginosa infections (pyocyaneus sepsis) in infancy. Germ. med. Mon. 9, 119.

Primavesi, C. A. (1964). Pyocyaneus-Hospitalismus auf einer Neugeborenenstation. Dt. med. Wschr. 27, 1303.

Public Health Laboratory Service Committee on Testing and Evaluation of DisINFECTANTS (1965). Use of disinfectants in hospitals. Br. med. J. i, 408.

Rubbo, S. D., Gardner, J. F. \& Franklin, J. C. (1966). Source of Pseudomonas aeruginosa infection in premature infants. J. Hyg., Camb. 64, 121.

Schaffer, A. J. \& Oppenhermer, E. H. (1948). Pseudomonas (Pyocyaneus) infection of the gastro-intestinal tract in infants and children. Sth. med. J., Nashville 41, 460.

SIERRA, G. (1957). A simple method for the detection of lipolytic activity of micro-organisms and some observations on the influence of contact between cells and fatty substrates. Antonie van Leeuwenhoek 23, 15.

Verger, P. \& Bentégeat, J. (1955). Une épidémie d'entérite à bacille pyocyanique (Pseudomonas aeruginosa) observeé dans un centre de prématurés. Nourrisson 43, 141.

WAHBA, A. H. \& DarReLL, J. H. (1965). The identification of atypical strains of Pseudomonas aeruginosa. J. gen. Microbiol. 38, 329.

Wensinck, F., van BekKUM, D. W. \& RenaUd, H. (1957). The prevention of Pseudomonas aeruginosa infections in irradiated mice and rats. Radiat. Res. 7, 491.

Wilson, M. G., Nelson, R. C., Phillips, L. H. \& Boak, R. A. (1961). New source of Pseudomonas aeruginosa in a nursery. J. Am. med. Ass. 175, 1146. 